\section{The U.S. Geological Survey in Maryland, Delaware, and Washington, D.C.}

\author{
by Daniel J. Soeder
}

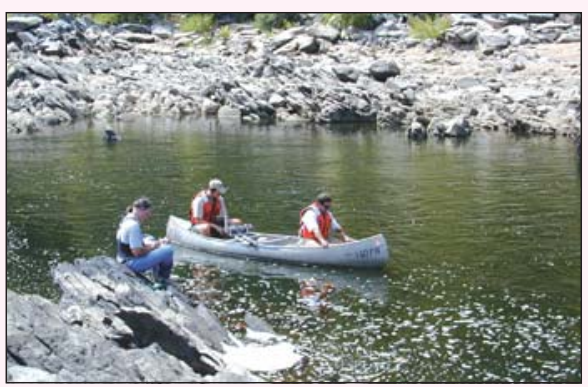

Chris Lewis, USGS

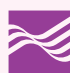

\section{Water Resources}

Information about the quantity and quality of water is vital to local governments and citizens. Floods and droughts affect all sectors of the economy, and threaten public safety. In cooperation with State and local Governments, the USGS collects streamflow data from about 140 gaging stations and groundwater data from nearly 380 wells in Maryland, Delaware, and Washington, D.C. Hydrologic conditions at many of these locations can be viewed in realtime over the web at:

http://md.water.usgs.gov/.

\section{Selected Projects of Interest}

\section{NAWOA}

Water quality of the Potomac River watershed and the Delmarva Peninsula is being assessed for the USGS National Water-Quality Assessment (NAWQA) Program. Visit the web at:

http://water.usgs.gov/nawqa/index.html.

\section{Department of Defense Programs}

The USGS is investigating environmental contamination in surface and ground water at military facilities such as Aberdeen Proving Ground, MD and Dover Air Force Base, DE. Sustainability of ground-water supplies is being characterized for the Naval Air Station, Patuxent River, MD.

\section{Urban Sprawl}

Urban sprawl is a common problem in the Mid-Atlantic region, which includes some of the oldest cities in the Nation and the heavily populated urban corridor from New York City to Richmond, VA. The USGS is leading an effort by a group of Federal agencies to provide sound and useful scientific information to State and local Governments for effective land-use planning.

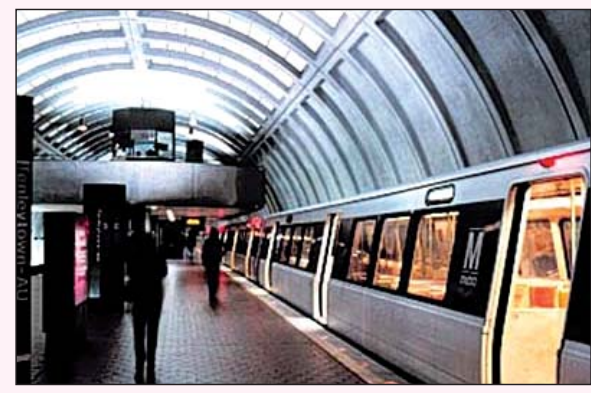

U.S. Department of Transportation

\section{WMATA}

The USGS is working with the Washington Metropolitan Area Transit Authority (WMATA) to investigate the sources of ground-water seepage into subway tunnels. Geologic and hydrologic data will be used to develop a strategy to help solve the seepage problem in WMATA underground facilities.

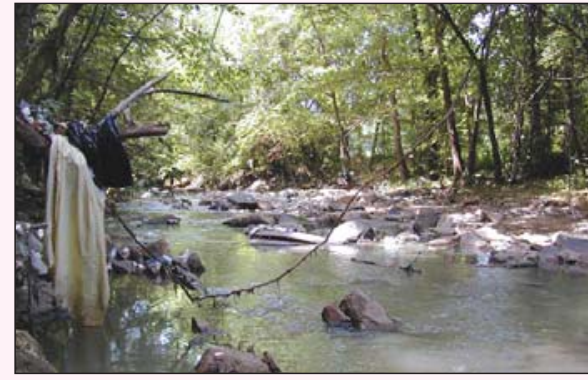

Gary Fisher, USGS

\section{Urban Hydrology}

Development of cities has a dramatic impact on streams. USGS studies on the Anacostia River and Rock Creek in

\section{MISSION OF THE} U.S. GEOLOGICAL SURVEY

The U.S. Geological Survey (USGS) is a Bureau of the Department of the Interior. Since 1879 , we have provided the Nation with reliable, impartial information to describe and understand the Earth.

\section{This information is used to:}

Minimize the loss of life and property from natural disasters;

$\checkmark$ Manage water, biological, energy, and mineral resources;

Enhance and protect the quality of life.

Washington, D.C., and Gwynns Run and Maidens Choice Run in Baltimore, MD have found that urban water quality is often degraded because of heavy stormwater runoff from paved areas and leakage from old sewers that pollute water, damage stream habitat, and cause erosion. These investigations are providing the basic information needed to advance our knowledge in the new field of urban hydrology.

\section{Chesapeake Bay Program}

The

Chesapeake Bay, the Nation's largest estuary, has suffered water-quality problems, loss of

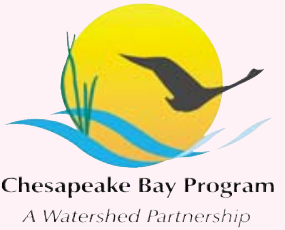
living resources, and habitat degradation. In response, a group of concerned Government agencies formed the Chesapeake Bay Program (CBP) to establish goals for restoring the Bay and its watershed. The USGS, one of the original CBP partners, has the important role of providing scientific information used to design, carry out, and assess the effectiveness of restoration. The USGS Chesapeake Bay Science Program is meeting these needs 
through environmental research, monitoring, computer modeling, and information transfer with our partners in the CBP. For more information, visit the web at: http://chesapeake.usgs.gov/chesbay/.

\section{Geography}

USGS regional programs consist of land-use mapping, investigations of urban development and sprawl, and use of satellite imagery to evaluate methods for controlling invasive plant species. A pilot program between the USGS and several State and local agencies was recently completed in Delaware on a new digital map product, produced using electronic data instead of paper. It will be used by the USGS as a template for a new National map. It is available on the web at: http://www.datamil.udel.edu/.

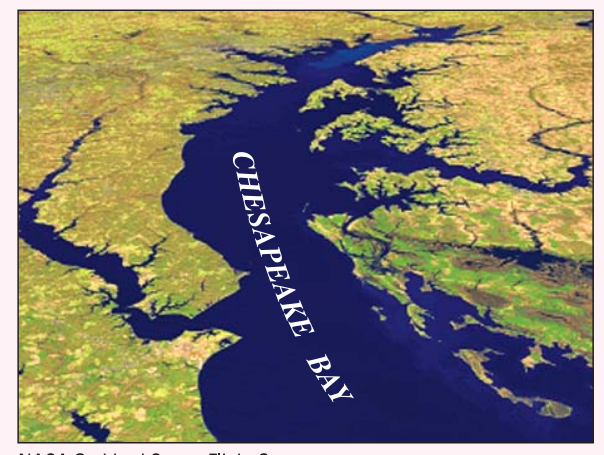

NASA Goddard Space Flight Center

\section{Geology}

Coastal areas are a vital resource for transportation, commerce, and recreation. Changes in the marine environment can endanger the quality of life, threaten property, pose a risk to fragile shorelines, and affect livelihoods. Parts of Maryland, Delaware, and Washington, D.C. are experiencing the effects of coastal erosion and sea-level rise. The USGS Coastal and Marine Geology Program provides scientific data to ensure careful use and protection of coastal and offshore resources. USGS investigations of coastal sediment transport and studies of the interaction of freshwater and saltwater in Maryland and Delaware coastal regions are contributing to this knowledge. For more information on the USGS Coastal and Marine Geology program, visit http://marine.usgs.gov/.

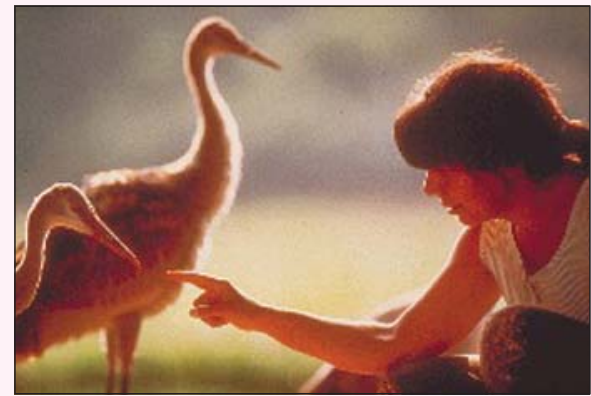

Trudy Harlow, USGS

\section{Biological Resources}

The USGS Biological Resources Discipline provides the information needed to help manage the Nation's plant and animal resources. The USGS Patuxent Wildlife Research Center in Laurel, MD is a leader in wildlife and applied environmental research to improve the management of biological resources. Patuxent's scientists are recognized leaders in the fields of migratory bird studies, wildlife population analysis, waterfowl harvest, habitat management, wetlands, coastal zone and flood-plain management, contaminants, endangered species, urban wildlife, ecosystem management, and management of National Parks and National Wildlife Refuges. The Center is responsible for the North American Bird Banding Program, the Breeding Bird Survey, and other national bird monitoring programs. The Center's scientific and technical assistance publications, wildlife data bases, and electronic media are used nationally and worldwide in managing biological resources. More information about the USGS Patuxent Wildlife Research Center can be found on the web at http://www.pwrc.usgs.gov/.

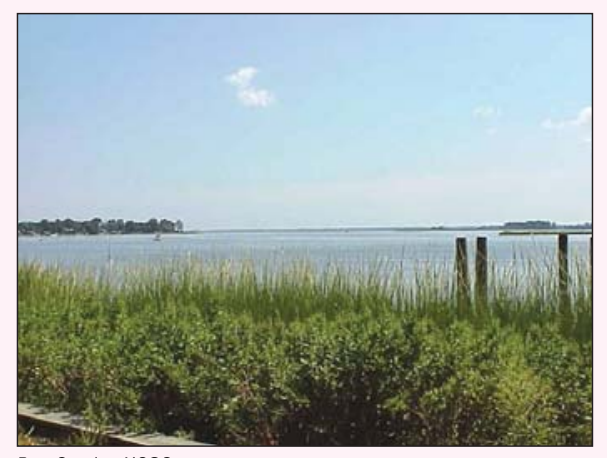

Dan Soeder, USGS
Editor: Valerie M. Gaine

Graphics and design: Timothy W. Auer

\section{Additional Information}

For additional information about these and other USGS activities, please contact:

District Chief, MD-DE-DC District

U.S. Geological Survey

8987 Yellow Brick Road

Baltimore, Maryland 21237

(410-238-4200)

Also visit the Maryland-DelawareDistrict of Columbia District Homepage on the World Wide Web at: http://md.water.usgs.gov/

or the USGS national Homepage at: http://www.usgs.gov/

Resources for teachers and students are available at: http://www.usgs.gov/education/

For information on natural hazards, volcanoes, earthquakes, floods and droughts, water supply, water quality, invasive species, ecology, natural resource issues, topographic maps, satellite imagery, and anything else related to Earth science, the USGS is YOUR source for science for a changing world.

FS 2004-3004

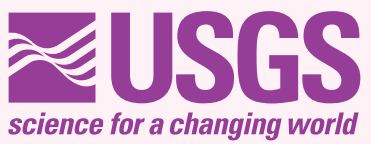

